\section{When gout goes to the heart: does gout equal a cardiovascular disease risk factor?}

\author{
Jasvinder A Singh ${ }^{1,2,3}$
}

Cardiovascular disease is among the leading causes of mortality in the world ${ }^{1}$ and its prevalence is rising over time. ${ }^{2}$ Inflammatory disorders such as rheumatoid arthritis and others are commonly associated with a higher risk and an earlier onset of cardiovascular disease. This increased risk may be mediated at least partially by non-traditional cardiovascular risk factors (inflammation and other disease activity factors), in addition to the traditional cardiovascular risk factors. ${ }^{3} 4$

In a study by Clarson et al, ${ }^{5}$ the authors found that gout was a risk factor in women for incident coronary heart disease, any vascular event and peripheral vascular disease, but not cerebrovascular disease. The cardiovascular risk associated with gout was lower in men. The study used the Clinical Practice Research Database (CPRD) that includes 3.5 million people in the UK from general practices, stated by the authors to be representative of the general population with gout. The authors compared 8386 patients with gout with 39766 non-gout patients. Despite the strengths of this study, including a large sample size, exclusion of patients with previously known heart disease and adjustment for important covariates, the study's findings must be interpreted in the light of two important limitations. First, the diagnoses of gout and most cardiac outcomes were not validated, but obtained from primary care records, which are likely to lead to some misclassification. Second, from an epidemiologic perspective, some people with disease may not seek care despite having access to healthcare due to either low/intermittent disease activity or personal health beliefs; also, there may be surveillance or detection bias because patients with gout may be more likely to visit primary care physicians than those

\footnotetext{
"Medicine Service, Birmingham VA Medical Center, Birmingham, Alabama, USA; ${ }^{2}$ Medicine and Division of Epidemiology, University of Alabama, Birmingham, Alabama, USA; ${ }^{3}$ Department of Orthopedic Surgery, Mayo Clinic College of Medicine, Rochester, Minnesota, USA

Correspondence to Dr Jasvinder A Singh, University of Alabama, Faculty Office Tower 805B, 510 20th Street S, Birmingham, AL 35294, USA; Jasvinder.md@gmail.com
}

who are healthy or do not have gout. Thus, the study's findings may be generally applicable to the UK population, but one may not have the same confidence in these findings as one would from a populationbased cohort study.

\section{IS GOUT A RISK FACTOR FOR INCIDENT HEART DISEASE?}

One of the key metabolic abnormalities in gout, hyperuricaemia, is known to be associated with increased risk of cardiovascular disease, although causality has not been proved. ${ }^{6-9}$ On the other hand, while there are some data suggesting that gout is a risk factor for incident heart disease, the overall literature in the area is somewhat mixed and debateable (table 1). The authors also cite it as the main reason for conducting the current study. The risk imparted by hyperuricaemia is of a small magnitude compared to other traditional cardiovascular risk factors, but it is significant. In addition, hyperuricaemia has also been shown to be a risk factor for peripheral vascular disease, another manifestation of atherosclerosis. ${ }^{1011}$ Some studies indicate that gout is an independent risk factor for incident cardiac disease (table 1).

\section{WHY DO GOUT PATIENTS HAVE HIGHER RISK OF CARDIOVASCULAR DISEASE? THE CONTRIBUTIONS OF ENDOTHELIAL DYSFUNCTION AND SYSTEMIC INFLAMMATION}

Gout, a metabolic disease associated with hyperuricaemia, leads to acute joint inflammation as part of a response to precipitation of urate crystals in the joint that commonly manifests as acute gout. Also, there is chronic inflammation around microtophi. Hyperuricaemia, a cardinal feature of gout, is associated with endothelial dysfunction, which may contribute to the risk of heart disease in patients with gout. ${ }^{12}$ However, depending on the chemical microenvironment, uric acid may have antioxidant or pro-oxidant function. ${ }^{13}$ In addition, uric acid likely contributes to the oxidation of lipoproteins within atherosclerotic plaque, thus contributing to the progression of lesions in coronary arteries. ${ }^{14}$ Gout is associated with systemic inflammation. Markers of systemic inflammation, such as erythrocyte sedimentation rate and $\mathrm{C}$ reactive protein, are often elevated during acute gouty arthritis ${ }^{15}$ and may even be raised in chronic active gouty arthritis. ${ }^{16}$ Studies have linked systemic inflammation to the risk of heart disease in other similar chronic systemic inflammatory conditions, such as rheumatoid arthritis and lupus. ${ }^{3} 1718$

A model for increased cardiovascular disease in gout is proposed, based on the current literature (figure 1). In the model, we allude to the mechanisms of cardiovascular disease, but due to lack of further evidence cannot propose what (hyperuricaemia vs acute inflammation vs chronic inflammation vs other yet unknown mechanism) exactly leads to that pathogenic step in cardiovascular risk (endothelial dysfunction, oxidation of low density lipoprotein (LDL), etc). Potential pathogenic mechanisms shown in patients with gout are either known (solid line) or suspected (dotted line). Similarly, the association of these mechanisms to the risk of heart disease is either known (solid line) or suspected (dotted line) in gout patients, or in general. For example, the association of hyperuricaemia (a cardinal feature of gout) with endothelial injury and acute and chronic inflammation is known, while its contribution to oxidation of LDL and elevation of other pro-atherogenic factors/ mechanisms/pathways is suspected.

\section{WHY DOES THE CARDIOVASCULAR RISK WITH GOUT DIFFER BY SEX?}

Heart disease risk differs by sex in the general population. Women have a lower risk of heart disease compared to agematched men in the pre-menopausal years -a protective effect of oestrogen. This benefit is lost in post-menopausal years and therefore the risk of heart disease in postmenopausal women catches up with men's risk of heart disease. Despite the differences in prevalence rates, the same risk factors for heart disease are key in both men and women-that is, smoking, diabetes, hypertension, hyperlipidaemia, and family history of heart disease. The early evidence from the current study and some others (table 1) indicates that the increase of heart disease risk might differ slightly by sex, the association being stronger in women compared to men. The absolute risk of any cardiovascular disease was 24.0/1000 person-years in men and 23.1/1000 personyears in women with gout, compared with 19.2 and 14.8/1000 person-years in men and women without gout, respectively. This shows that there is a difference in the risk of cardiovascular disease by sex in patients without gout and that this sex difference in cardiovascular disease risk is abolished in 
Table 1 Summary of large studies assessing the risk of cardiac disease in patients with gout

\begin{tabular}{|c|c|c|c|}
\hline $\begin{array}{l}\text { Study/country/ } \\
\text { randomised vs cohort }\end{array}$ & Population & $\begin{array}{l}\text { Odds/risk/hazard ratios }(95 \% \\
\text { Cl p value) }\end{array}$ & $\begin{array}{l}\text { Covariates adjusted for in multivariable adjusted } \\
\text { model }\end{array}$ \\
\hline Krishnan et $a l^{21} /$ USA/MRFIT & $\begin{array}{l}12866 \text { men in the MRFIT who were followed } \\
\text { up for a mean of } 6.5 \text { years }\end{array}$ & $\begin{array}{l}\text { Hyperuricaemia and MI: OR } 1.11 \\
\text { ( } 95 \% \text { Cl } 1.08 \text { to } 1.15) \\
\text { Gout and MI: OR } 1.26(95 \% \mathrm{Cl} \\
1.14 \text { to } 1.40)\end{array}$ & $\begin{array}{l}\text { Age, diastolic blood pressure, total serum cholesterol, } \\
\text { BMI, fasting blood glucose, smoking, creatinine, diuretic } \\
\text { use, aspirin use, alcohol use, incident diabetes, family } \\
\text { history of acute MI }\end{array}$ \\
\hline $\begin{array}{l}\text { Abbott et } a l^{22} / \text { USA/ } \\
\text { Framingham }\end{array}$ & $\begin{array}{l}5209 \text { subjects originally enrolled in the } \\
\text { Framingham Study }\end{array}$ & $\begin{array}{l}\text { Gout and coronary heart disease: } \\
\text { RR } 1.60(95 \% \mathrm{Cl} 1.1 \text { to } 2.2) \text { in } \\
\text { men }\end{array}$ & $\begin{array}{l}\text { Systolic blood pressure, total cholesterol, alcohol intake, } \\
\text { body mass index, and diabetes }\end{array}$ \\
\hline $\begin{array}{l}\text { Gelber et al }{ }^{23} / \text { USA/two } \\
\text { cohorts of black and white } \\
\text { physicians }\end{array}$ & $\begin{array}{l}\text { Prospective cohort studies of former medical } \\
\text { students-371 black men in the Meharry } \\
\text { Cohort Study and } 1181 \text { white men in the } \\
\text { Johns Hopkins Precursors Study }\end{array}$ & $\begin{array}{l}\text { Gout and incident CHD: RR } 1.20 \\
(95 \% \mathrm{Cl} 0.37 \text { to } 3.92) \text { in Meharry } \\
\text { men } \\
\text { RR } 0.66 \text { ( } 95 \% \mathrm{Cl} 0.24 \text { to } 1.79) \text { in } \\
\text { Johns Hopkins men }\end{array}$ & Known CHD risk factors \\
\hline $\begin{array}{l}\text { Janssens et } \mathrm{a}^{24} \mathrm{I} \\
\text { Netherlands/case-control }\end{array}$ & $\begin{array}{l}\text { Data were obtained from the Continuous } \\
\text { Morbidity Registration (CMR), Nijmegen }\end{array}$ & $\begin{array}{l}\text { Gout and incident CVS disease: } \\
\text { RR } 0.98 \text { (95\% Cl } 0.65 \text { to } 1.47)\end{array}$ & Matched for age, sex and practice \\
\hline $\begin{array}{l}\text { De Vera et } a l^{25} / \text { British } \\
\text { Columbia/population-based } \\
\text { cohort }\end{array}$ & $\begin{array}{l}9642 \text { gout patients and } 48210 \text { controls, with } \\
\text { no history of ischaemic heart disease }\end{array}$ & $\begin{array}{l}\text { Gout in women: RR } 1.39 \text { ( } 95 \% \\
\text { Cl } 1.20 \text { to } 1.61) \text { for all AMI and } \\
\text { RR } 1.41 \text { ( } 95 \% \text { Cl } 1.19 \text { to } 1.67) \\
\text { for non-fatal AMl } \\
\text { Gout in men: RR } 1.11 \text { ( } 95 \% \text { Cl } \\
0.99 \text { to } 1.23 \text { ) for all AMI and } \\
\text { RR } 1.11 \text { ( } 95 \% \text { Cl } 0.98 \text { to } 1.25) \\
\text { for non-fatal AMI }\end{array}$ & $\begin{array}{l}\text { Age, comorbidities (hypertension, diabetes, COPD, and } \\
\text { hyperlipidaemia), Charlson comorbidity score and } \\
\text { prescription drug use (non-steroidal anti-inflammatory } \\
\text { drugs, aspirin, glucocorticoids, statins, anticoagulants, } \\
\text { hormone replacement therapy and diuretics) as } \\
\text { time-dependent covariates }\end{array}$ \\
\hline $\begin{array}{l}\text { Choi et } a l^{26} / \text { Health } \\
\text { Professionals Follow-up } \\
\text { Study/cohort }\end{array}$ & $\begin{array}{l}51297 \text { male participants of the Health } \\
\text { Professionals Follow-Up Study with } 12 \text { year } \\
\text { follow-up }\end{array}$ & $\begin{array}{l}\text { In patients with no pre-existing } \\
\text { CAD-Gout and total mortality: } \\
\text { RR } 1.28 \text { ( } 95 \% \text { Cl } 1.15 \text { to } 1.41 \text { ) } \\
\text { Gout and CVD deaths: RR } 1.38 \\
\text { (95\% CI } 1.15 \text { to } 1.66) \\
\text { Gout and fatal CHD: RR } 1.55 \\
\text { (95\% Cl } 1.24 \text { to 1.93) }\end{array}$ & $\begin{array}{l}\text { Age, hypertension, hypercholesterolaemia, diabetes } \\
\text { mellitus, aspirin use, diuretic use, smoking, body mass } \\
\text { index, alcohol intake, family history of Ml, total energy } \\
\text { intake, trans fat, dietary cholesterol, protein, linoleic } \\
\text { fatty acid, and the ratio of polyunsaturated fat to } \\
\text { saturated fat }\end{array}$ \\
\hline $\begin{array}{l}\text { Cohen et a } P^{27} / \text { US Renal } \\
\text { Data System dialysis } \\
\text { subjects }\end{array}$ & $\begin{array}{l}234794 \text { patients on dialysis in the US Renal } \\
\text { Data System }\end{array}$ & $\begin{array}{l}\text { Gout and mortality: HR } 1.47 \\
\text { (95\% CI } 1.26 \text { to } 1.59 \text { ) }\end{array}$ & $\begin{array}{l}\text { Age, sex, diabetes, COPD, peripheral vascular disease, } \\
\text { smoking, ischaemic heart disease, congestive heart } \\
\text { failure, albumin, smoking }\end{array}$ \\
\hline $\begin{array}{l}\text { Kuo et } a{ }^{28} / \text { Chang Gung } \\
\text { Memorial Hospital in } \\
\text { Taiwan }\end{array}$ & 61527 subjects, with 1311 with gout & $\begin{array}{l}\text { Gout and all-cause death: HR } \\
1.46(95 \% \mathrm{Cl} 1.12 \text { to } 1.91) \\
\text { Hyperuricaemia and all-cause } \\
\text { death: HR } 1.07 \text { ( } 95 \% \mathrm{Cl} 0.94 \text { to } \\
1.22 \text { ) }\end{array}$ & $\begin{array}{l}\text { Age, sex, component number of metabolic syndrome and } \\
\text { proteinuria }\end{array}$ \\
\hline
\end{tabular}

AMI, acute myocardial infarction; BMI, body mass index, CAD, coronary artery disease; CHD, coronary heart disease; COPD, chronic obstructive pulmonary disease; CVD, cardiovascular disease; CVS, cardiovascular; MI, myocardial infarction; MRFIT, Multiple Risk Factor Intervention Trial; RR, relative risk.

men and women with gout. It is possible that systemic inflammation induced by gout in women, who otherwise have a lower prevalence of cardiac risk factors than agematched men, is more atherogenic than that in men. Studies are needed to test whether there are sex-based differences in the pathogenesis of gout-associated heart disease.

\section{DOES THIS MEAN GOUT PATIENTS SHOULD BE CAREFULLY SCREENED FOR CARDIOVASCULAR DISEASE RISK FACTORS?}

Considering the ease of screening for risk factors, the suggestion is to screen gout patients older than 35 years (arbitraryone may pick 40 years, for instance) with fasting lipid profile and glycated haemoglobin (HbA1c) monitoring, blood pressure measurement and current smoking status, and counsel/discuss with the patient if any risk factors are present. Patients should also be screened at regular intervals if their baseline is not normal and managed aggressively. Regardless of causality, the fact remains that patients with gout have a higher prevalence of numerous comorbidities, each of which can contribute to cardiovascular risk, and therefore require appropriate screening and management, as suggested by previous gout guidelines. ${ }^{19} 20$ Since most gout patients receive care from primary care physicians, rather than rheumatologists, this is relatively easy. The only difference from the general population is an earlier age for screening, given the increased prevalence of cardiovascular disease risk factors in patients with gout and an increased associated risk. The goals are to prevent the onset of heart disease in patients with gout, and in those with early evidence of heart disease based on the workup with traditional markers and surrogates (such as serological and imaging biomarkers), institute treatments to improve outcomes.

\section{WHAT SHOULD CHANGE IN PRIMARY CARE AND RHEUMATOLOGY PRACTICE BASED ON THESE DATA?}

The end-organ damage from gout may not be limited only to the musculoskeletal system. Evidence is accumulating that the presence of gout matters for cardiac and vascular health, just as it does for joint health. It is to our advantage that a significant proportion of gout patients are managed by internists and cardiologists. A small, but significant, proportion of patients with gout may see cardiologists in addition to internists due to refractory pre-existing/concomitant cardiac conditions (coronary heart disease, congestive heart failure) and/or risk factors (hyperlipidaemia, hypertension, etc). However, in some of these cases, the cardiac or vascular disease has already manifested, meaning the window of opportunity may have been missed, and only secondary prevention (avoiding future myocardial infarction, etc) is possible. Real progress 
Pathogenesis of heart

disease

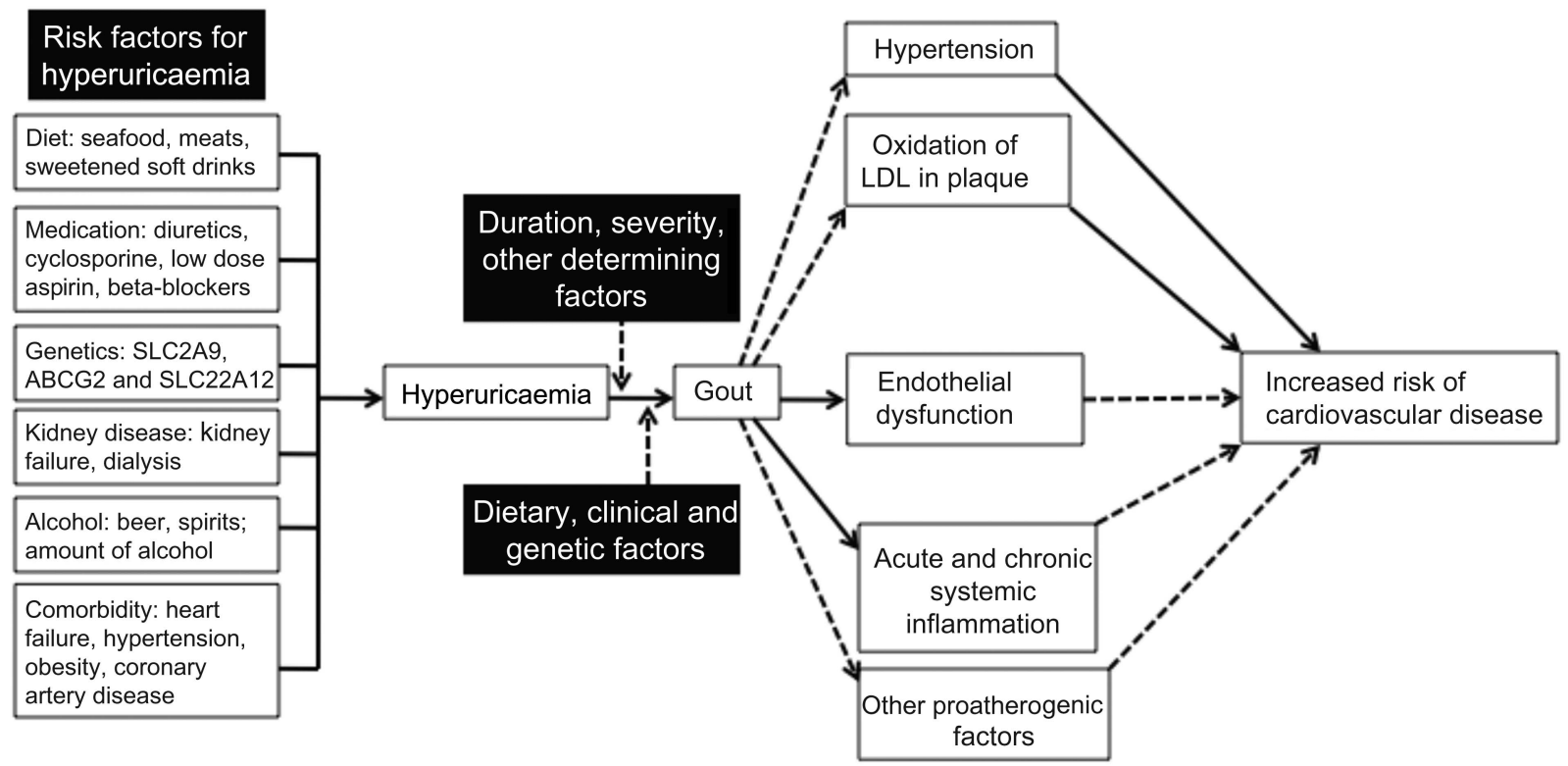

Figure 1 Potential pathogenic pathways for higher risk of cardiovascular disease in patients with gout. Solid lines indicate current evidence supporting the mechanism/pathway and dotted lines indicate potential mechanism/pathway, for which more evidence is needed. Several links from gout to the intermediate event (endothelial dysfunction, etc) may be through (mediated by) hyperuricaemia or non-hyperuricaemic pathways (eg, systemic inflammation).

in the care of gout patients can be measured by our ability to improve overall outcomes in gout patients including proactive recognition, early diagnosis, and optimisation of the treatment of heart disease-that is, primary prevention.

Primary prevention is always the goal of an epidemiologist, since the public health and individual level impact is much more substantial than secondary or tertiary prevention. It is very desirable to intervene early in high risk patients to modify traditional and non-traditional cardiac and vascular disease risk factors, before cardiac disease actually manifests. Mitigation of traditional cardiovascular disease risk factors such as hypertension is key to reducing this risk. Another approach might be to target and reduce systemic inflammation due to chronic gouty arthritis as well as acute gouty arthritis, by providing optimal urate-lowering (and anti-inflammatory) therapy, in order to additionally (potentially) prevent or delay the onset of cardiac disease in patients with gout. An effectiveness trial where the intervention targets systemic inflammation, with a sample size large enough to study cardiovascular disease or a surrogate outcome, is needed to test the following hypothesis: Does reduction in systemic inflammation in gout decrease the risk of cardiac disease and improve outcomes? Such a study will generate data that can lead to a change in the clinical practice for the treatment of gout. I anticipate that in the next decade aggressive management of gout will be key to implementing a 'healthier heart programme in gout'.

In summary, considerable data show an increased risk of cardiac disease in patients with gout, above and beyond that contributed by the traditional risk factors for heart disease. It is not known whether gout is an equivalent risk factor for cardiovascular disease to conditions such as diabetes or not. Future studies need to address this important question. At least two studies, including the current study, suggest that there may be an interaction with sex, meaning that the relative risk is different for men versus women. An implication of this new knowledge is that gout patients should be monitored and screened regularly for cardiovascular disease. Those with existing risk factors, such as hypertension, smoking, diabetes, hyperlipidaemia and others, are likely to be at high risk for cardiovascular disease. A comprehensive approach to treating uric acid appropriately to a target level, and to diagnosing and treating cardiac disease early, may lead to improved outcomes in patients with gout.

Acknowledgements I thank Dr Ralph Schumacher and Dr Tuhina Neogi for their critical comments on this editorial.

Contributors JAS conceived and wrote the editorial and made the decision to submit it.
Funding This material is the result of work supported by research funds from the Division of Rheumatology at the University of Alabama at Birmingham and the resources and use of facilities at the Birmingham VA Medical Center, Alabama, USA. JAS is also supported by grants from the Agency for Health Quality and Research Center for Education and Research on Therapeutics (AHRQ CERTs) U19 HS021110, National Institute of Arthritis, Musculoskeletal and Skin Diseases (NIAMS) P50 AR060772 and U34 AR062891, National Institute of Aging (NIA) U01 AG018947, and National Cancer Institute (NCI) U10 CA149950, and research contract CE-1304-6631 from Patient Centered Outcomes Research Institute (PCORI)

Competing interests JAS has received research and travel grants from Takeda and Savient; and consultant fees from Savient, Takeda, Regeneron and Allergan.

Provenance and peer review Commissioned; externally peer reviewed.

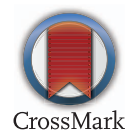

To cite Singh JA. Ann Rheum Dis 2015;74:631-634. Received 11 October 2014 Revised 9 December 2014 Accepted 14 December 2014

Published Online First 20 January 2015

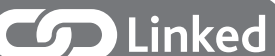

- http://dx.doi.org/10.1136/annrheumdis-2014-205252

Ann Rheum Dis 2015;74:631-634.

doi:10.1136/annrheumdis-2014-206432 


\section{REFERENCES}

1 Mathers CD, Loncar D. Projections of global mortality and burden of disease from 2002 to 2030. PLoS Med 2006;3:e442.

2 Ford ES, Giles WH, Mokdad AH. Increasing prevalence of the metabolic syndrome among U.S. adults. Diabetes Care 2004;27:2444-9.

3 del Rincon ID, Williams K, Stern MP, et al. High incidence of cardiovascular events in a rheumatoid arthritis cohort not explained by traditional cardiac risk factors. Arthritis Rheum 2001:44:2737-45.

4 Sattar N, McCarey DW, Capell H, et al. Explaining how "high-grade" systemic inflammation accelerates vascular risk in rheumatoid arthritis. Circulation 2003;108:2957-63.

5 Clarson LE, Hider SL, Belcher J, et al. Increased risk of vascular disease associated with gout: a retrospective, matched cohort study in the UK Clinical Practice Research Datalink. Ann Rheum Dis 2015;74:642-7.

6 Johnson RJ, Kang DH, Feig D, et al. Is there a pathogenetic role for uric acid in hypertension and cardiovascular and renal disease? Hypertension 2003;41:1183-90.

7 Kim SY, Guevara JP, Kim KM, et al. Hyperuricemia and risk of stroke: a systematic review and meta-analysis. Arthritis Rheum 2009;61:885-92.

8 Kim SY, Guevara JP, Kim KM, et al. Hyperuricemia and coronary heart disease: a systematic review and meta-analysis. Arthritis Care Res (Hoboken) 2010;62:170-80.

9 Feig DI, Kang DH, Johnson RJ. Uric acid and cardiovascular risk. N Engl J Med 2008;359:1811-21.
10 Shankar A, Klein BE, Nieto FJ, et al. Association between serum uric acid level and peripheral arterial disease. Atherosclerosis 2008;196:749-55.

11 Baker JF, Schumacher HR, Krishnan E. Serum uric acid level and risk for peripheral arterial disease: analysis of data from the multiple risk factor intervention trial. Angiology 2007;58:450-7.

12 Khosla UM, Zharikov S, Finch JL, et al. Hyperuricemia induces endothelial dysfunction. Kidney Int 2005;67:1739-42.

13 So A, Thorens B. Uric acid transport and disease. J Clin Invest 2010;120:1791-9.

14 Hayden MR, Tyagi SC. Uric acid: a new look at an old risk marker for cardiovascular disease, metabolic syndrome, and type 2 diabetes mellitus: The urate redox shuttle. Nutr Metab 2004;1:10.

15 Roseff R, Wohlgethan JR, Sipe JD, et al. The acute phase response in gout. J Rheumatol 1987;14:974-7.

16 Terkeltaub R, Sundy JS, Schumacher HR, et al. The interleukin 1 inhibitor rilonacept in treatment of chronic gouty arthritis: results of a placebo-controlled, monosequence crossover, non-randomised, single-blind pilot study. Ann Rheum Dis 2009;68:1613-17.

17 Svenungsson E, Jensen-Urstad K, Heimburger $M$, et al. Risk factors for cardiovascular disease in systemic lupus erythematosus. Circulation 2001;104:1887-93.

18 Bruce IN, Urowitz MB, Gladman DD, et al. Risk factors for coronary heart disease in women with systemic lupus erythematosus: the Toronto Risk Factor Study. Arthritis Rheum 2003;48:3159-67.

19 Zhang W, Doherty M, Pascual E, et al. EULAR evidence based recommendations for gout. Part I: Diagnosis. Report of a task force of the Standing Committee for
International Clinical Studies Including Therapeutics (ESCISIT). Ann Rheum Dis 2006;65:1301-11.

20 Zhang W, Doherty M, Bardin T, et al. EULAR evidence based recommendations for gout. Part II: Management. Report of a task force of the EULAR Standing Committee for International Clinical Studies Including Therapeutics (ESCISIT). Ann Rheum Dis 2006;65:1312-24

21 Krishnan E, Baker JF, Furst DE, et al. Gout and the risk of acute myocardial infarction. Arthritis Rheum 2006;54:2688-96.

22 Abbott RD, Brand FN, Kannel WB, et al. Gout and coronary heart disease: the Framingham Study. J Clin Epidemiol 1988;41:237-42.

23 Gelber AC, Klag MJ, Mead LA, et al. Gout and risk for subsequent coronary heart disease. The MeharryHopkins Study. Arch Intern Med 1997;157:1436-40.

24 Janssens HJ, van de Lisdonk EH, Bor $\mathrm{H}$, et al. Gout, just a nasty event or a cardiovascular signal? A study from primary care. Fam Pract 2003;20:413-16.

25 De Vera MA, Rahman MM, Bhole V, et al. Independent impact of gout on the risk of acute myocardial infarction among elderly women: a population-based study. Ann Rheum Dis 2010;69:1162-4.

26 Choi HK, Curhan G. Independent impact of gout on mortality and risk for coronary heart disease. Circulation 2007;116:894-900.

27 Cohen SD, Kimmel PL, Neff R, et al. Association of incident gout and mortality in dialysis patients. J Am Soc Nephrol 2008;19:2204-10.

28 Kuo CF, See LC, Luo SF, et al. Gout: an independent risk factor for all-cause and cardiovascular mortality. Rheumatology (Oxford) 2010;49:141-6. 